\title{
Behaviour of solute and particle markers in the stomach of sheep given a concentrate diet
}

\author{
BY G. J. FAICHNEY \\ CSIRO, Division of Animal Production, Ian Clunies Ross Animal Research Laboratory, \\ Prospect, P.O. Box 239, Blacktown, NSW 2148, Australia \\ AND D. A. GRIFFITHS \\ CSIRO, Division of Mathematics and Statistics, Newtown, NSW 2024, Australia
}

(Received 10 January 1977 - Accepted 27 July 1977)

\begin{abstract}
I. Fistulated sheep given a concentrate diet were used to study the behaviour of solute $\left(\left[{ }^{51} \mathrm{Cr}\right] \mathrm{EDTA}\right)$ and particle ([ $\left.{ }^{103} \mathrm{Ru}\right]$ phenanthroline) markers in the stomach under conditions of continuous feeding.

2. An injection of a mixed dose of $\left[{ }^{51} \mathrm{Cr}\right] E D T A$ and $\left[{ }^{103} \mathrm{Ru}\right]$ phenanthroline was given into the rumen and the time course of marker concentrations in the rumen and the abomasum was recorded. The curves were analysed on the assumption that the stomach of the sheep could be represented as two mixing compartments (reticulo-rumen and abomasum) and a time delay (omasum). This model provided a very good description of the data.

3. $\left[{ }^{103} \mathrm{Ru}\right]$ phenanthroline associated with small particles was retained in the rumen much longer than $\left.{ }^{51} \mathrm{Cr}\right] E D T A$. Although exchange of $\left[{ }^{103} \mathrm{Ru}\right]$ phenanthroline occurred between large and small particle fractions, the results suggested that small particles may have been retained somewhat longer in the rumen than solutes. However, it was clear from the results that the mean retention times for particulate matter in the rumen could not be simply obtained using adsorbable markers.

4. Cyclical fluctuations in the concentration of $\left[^{51} \mathrm{Cr}\right]$ EDTA in the rumen indicated that there were daily variations in net water flux in the rumen.

5. The presence of protozoa was associated with much shorter retention times of both solutes and particles in the rumen. Protozoa were also associated with reduced rumen volumes.
\end{abstract}

Events occurring in the rumen have a profound influence on the supply of nutrients to the tissues of sheep. In order to understand more fully the processes of digestion, a knowledge of the mean retention time and rate of removal of particular components of the diet is required. Provided the behaviour of the markers used does not deviate too greatly from the ideal (Faichney, 1975a), such information could be obtained from the analysis of marker concentration patterns.

Marker excretion patterns in the faeces of sheep have been described by a model consisting of two exponential components and a time delay (Blaxter, Graham \& Wainman, 1956; Matis \& Hartley, 197I; Ellis, Goodell \& Matis, 1972; Grovum \& Williams, 1973b). It has been suggested that the exponential components represent passage through two mixing compartments, the reticulo-rumen and the caecum-colon, and that the time delay represents passage (or transit) through the omasum and small intestine (Grovum \& Williams, $1973 b$ ). However, the abomasum also acts as a mixing compartment (Grovum \& Williams, $1973 a$; Faichney, I975 $b$ ) and the reticulo-rumen may not act as a simple mixing compartment; the effects of these factors may not be apparent in the faecal excretion pattern.

This paper investigates the passage of indigestible markers through the stomach (i.e. rumen, reticulum, omasum and abomasum) of sheep given concentrate diets. The markers used were the ${ }^{51} \mathrm{Cr}$ complex of ethylenediaminetetra-acetic acid $\left(\left[{ }^{51} \mathrm{Cr}\right] \mathrm{EDTA}\right)$ (Downes \& McDonald, I964) which remains in solution and ${ }^{103} \mathrm{Ru}$-labelled tris-(I,IO-phenanthroline) ruthenium (II) chloride $\left(\left[{ }^{103} \mathrm{Ru}\right] \mathrm{P}\right)$ (Tan, Weston \& Hogan, I 97I) which is strongly adsorbed by particulate matter. Data from two experiments were subjected to compartmental analysis. 
The first analysis was of the marker concentrations in digesta from the rumen and abomasum obtained during an experiment for which the effect of formaldehyde treatment of the diet on the faecal excretion of the markers and their mean retention times within the gastro-intestinal tract has been reported (Faichney, 1975b). In the second experiment, the behaviour of $\left[{ }^{103} \mathrm{Ru}\right] \mathrm{P}$ was further studied by analysing the data obtained after dividing the digesta dry matter (DM) into 'small' and 'large' particles by straining through Terylene cloth (Weston \& Hogan, 1967).

\section{MATERIALS AND METHODS}

\section{Animals}

The animals used in this experiment were mature crossbred wethers (Border Leicester $\times$ Merino) which had been fitted with cannulas in the rumen, in the abomasum near the pylorus and in the terminal ileum. They were maintained in metabolism cages indoors with continuous lighting and were dosed with retinol and cholecalciferol before the beginning of the experiment. Their mean live weight was approximately $47 \mathrm{~kg}$.

\section{Diet and feeding}

The diet, which was pelleted, contained $(\mathrm{g} / \mathrm{kg})$ : rolled barley 700 ; lucerne hay, ground to pass a $3 \mathrm{~mm}$ screen, 70; dried molasses 20; wheat starch 70; soya-bean meal I 40. The following minerals were added to the diet $(\mathrm{mg} / \mathrm{kg}): \mathrm{CaCO}_{3} 4000 ; \mathrm{CaHPO}_{4} .2 \mathrm{H}_{2} \mathrm{O}$ I0000; $\mathrm{NaCl}$ $5000 ; \mathrm{CoSO}_{4} \cdot 7 \mathrm{H}_{2} \mathrm{O}_{2} ; \mathrm{CuSO}_{4} \cdot 5 \mathrm{H}_{2} \mathrm{O} 4 ; \mathrm{FeSO}_{4} \cdot 7 \mathrm{H}_{2} \mathrm{O} 300 ; \mathrm{ZnSO}_{4} \cdot 7 \mathrm{H}_{2} \mathrm{O} 200 ; \mathrm{MnSO}_{4} \cdot \mathrm{H}_{2} \mathrm{O}$ I20; KI I. For Expt $\mathrm{I}$ the diet was made up and treated with formaldehyde as described previously (Faichney, $1975 \mathrm{~b}$ ). The organic matter and nitrogen contents of the DM $(869 \mathrm{~g} / \mathrm{kg})$ were, respectively, 952 and $24 \cdot 8 \mathrm{~g} / \mathrm{kg}$.

For Expt 2, which was performed several months after Expt I, a new batch of the diet was prepared. The organic matter and N contents of its DM $(879 \mathrm{~g} / \mathrm{kg})$ were, respectively, 946 and $33.6 \mathrm{~g} / \mathrm{kg}$.

In the first experiment, the sheep were given the untreated diet (U) in the first period of the experiment and the treated diet (T) in the second period (Faichney, 1975b). In both experiments, the diets were given at the rate of $1000 \mathrm{~g} / \mathrm{d}$ continuously from a moving belt and sampling commenced after 3 weeks of feeding.

\section{Expt I}

\section{Experimental procedure}

Rumen dose. For each sheep, approximately $100 \mu \mathrm{Ci}\left[{ }^{51} \mathrm{Cr}\right.$ ]EDTA and approximately $20 \mu \mathrm{Ci}\left[{ }^{103} \mathrm{Ru}\right] \mathrm{P}$ were mixed with approximately $30 \mathrm{ml}$ of a slurry of ground feed (approximately $5 \mathrm{~g}$ ) in water and incubated at room temperature overnight. The dose was introduced into the rumen via the cannula at about 09.00 hours and samples were taken at frequent intervals from the rumen for $36 \mathrm{~h}$ after dosing and from the abomasum for $96 \mathrm{~h}$ after dosing.

Abomasum dose. For each sheep on a separate occasion approximately $50 \mu \mathrm{Ci}\left[{ }^{51} \mathrm{Cr}\right]-$ EDTA and approximately $10 \mu \mathrm{Ci}\left[{ }^{103} \mathrm{Ru}\right] \mathrm{P}$ were mixed with approximately $30 \mathrm{ml}$ abomasal digesta and incubated at room temperature overnight. The dose was introduced into the abomasum at about 09.00 hours and samples were taken during the next $9 \mathrm{~h}$.

\section{Expt 2}

The marker dose was prepared as in Expt $\mathrm{r}$. It was introduced into the rumen via the cannula at about 09.00 hours and samples were taken at frequent intervals from the rumen and the abomasum for $60 \mathrm{~h}$ after dosing. 


\section{Sample preparation and radioactivity measurements}

In Expt I, rumen and abomasal digesta samples were strained through Terylene cloth (Weston \& Hogan, 1967 ) and ${ }^{51} \mathrm{Cr}$ and ${ }^{103} \mathrm{Ru}$ were assayed simultaneously in duplicate $3 \mathrm{ml}$ portions of the filtrate using a model 52 I 2 Auto-Gamma spectrometer (Packard Instrument Co., Illinois, USA).

In Expt 2, samples of rumen and abomasal digesta (approximately $10 \mathrm{~g}$ ), as well as fluid obtained by straining through Terylene cloth, were assayed for ${ }^{51} \mathrm{Cr}$ and ${ }^{103} \mathrm{Ru}$ simultaneously in duplicate tared vials using a model 5320 Auto-Gamma spectometer (Packard Instrument Co.). The vials were counted for $10 \mathrm{~min}$ and were then placed in an oven at $105^{\circ}$ for $24 \mathrm{~h}$ for the determination of water and DM content. ${ }^{51} \mathrm{Cr}$ and ${ }^{103} \mathrm{Ru}$ concentrations (as counts/min) were expressed on the basis of, respectively, the water and DM content of the samples. The ${ }^{103} \mathrm{Ru}$ content of the filtrand (large particles) was calculated from the DM and ${ }^{103} \mathrm{Ru}$ content of digesta and filtrate (small particles). Samples of rumen fluid (filtrate) were fixed in formolsaline ( $9 \mathrm{~g}$ sodium chloride $/ \mathrm{l}, \mathrm{I}: 4 \mathrm{v} / \mathrm{v}$ ) for microscopic examination.

\section{Radioactive markers}

$\left[{ }^{51} \mathrm{Cr}\right]$ EDTA was obtained from the Australian Atomic Energy Commission, Lucas Heights, NSW, Australia; its specific activity was reduced by the addition of unlabelled [Cr]EDTA to each dose. ${ }^{103} \mathrm{RuCl}_{3}$ (in $4 \mathrm{M}-\mathrm{HCl}$ ) was obtained from the Radiochemical Centre, Amersham, Bucks, UK and converted to the phenanthroline complex (Tan et al. 1971).

\section{Data analysis}

Compartmental models of the stomach were fitted to the data using an iterative least squares procedure. For the rumen dose data, rumen and abomasum curves were first analysed independently. The combined data were then analysed simultaneously to obtain pooled estimates of the parameters. The first datum for the abomasum was not included in the analyses because the first sample was taken before mixing in the rumen was complete.

The stomach of the sheep may be represented by either of the following two models:

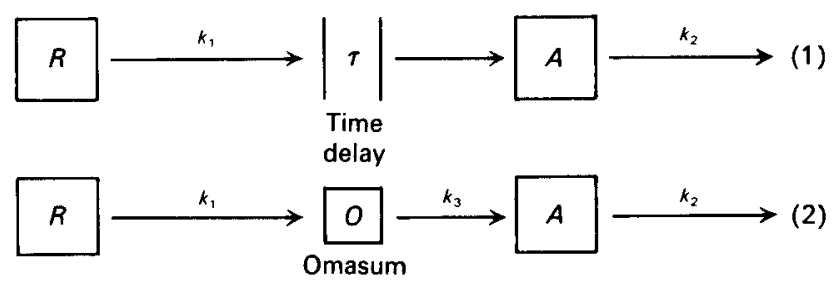

where $R$ is the amount of marker in the rumen, $O$ is the amount of marker in the omasum, $A$ is the amount of marker in the abomasum, $\tau$ is a time delay and $k_{1}, k_{2}$ and $k_{3}$ are fractional outflow rates.

However, analysis of the data for ${ }^{51} \mathrm{Cr}$ and ${ }^{103} \mathrm{Ru}$ in filtrate from Expt I showed that there was little difference in the fit of models I and 2. Since it seems unlikely on the basis of its structure that the omasum would act as a mixing compartment, it has been represented as a time delay in the analyses reported here.

In Expt 2, the concentrations of ${ }^{103} \mathrm{Ru}$ in large particles $(L)$ and small particles $(S)$ in the 
rumen were initially analysed using model 3 which incorporates a breakdown of large to small particles within the rumen:

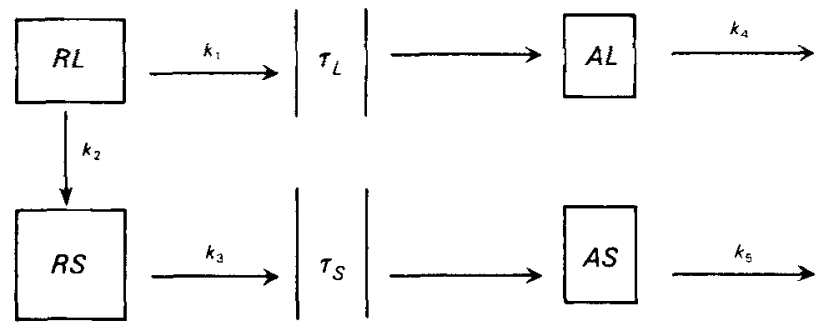

There was no significant improvement in fit to the data when model 3 was compared with the use of model I for both large and small particles. Therefore all data from both experiments were finally analysed using model $\mathrm{I}$.

Small and large particles and water were all constituents of a single digesta sample. This implies some degree of correlation in the data but this has been ignored in the independent analyses for each of these constituents. Correlation between rumen and abomasal values for each of these constituents was also ignored.

Model I is governed by the differential equations:

$$
\begin{aligned}
& \frac{d R}{d t}=-k_{1} R(t), \quad(t>0), \\
& \frac{d A}{d t}=-k_{2} A(t)+k_{1} R(t-\tau), \quad(t>\tau),
\end{aligned}
$$

where $R$ is the quantity of marker in the rumen, $A$ is the quantity of marker in the abomasum, $t$ is the time after dosing and $\tau$ is the time taken by a marker molecule to pass between the rumen and the abomasum. The solution of these equations is:

$$
\begin{aligned}
& R(t)=R_{o} \exp \left(-k_{1} t\right), \\
& A(t)=\frac{k_{1} R_{o}}{k_{2}-k_{1}}\left\{\exp \left[-k_{1}(t-\tau)\right]-\exp \left[-k_{2}(t-\tau)\right]\right\},
\end{aligned}
$$

for $t \geqslant \tau$,

$$
=0 \text { for } t<\tau \text {, }
$$

where $R_{o}$ is the initial dose of marker into the rumen. If the volume of the compartments is assumed to be constant (steady state), equations similar to equations (3) and (4) govern the changes in concentration with time in both the rumen and abomasum except that the terms multiplying the exponential terms $\left(R_{o}\right.$ and $\left.k_{1} R_{o} / k_{2}-k_{1}\right)$ are replaced by, say, $R^{\prime}$ and $A^{\prime}$ respectively. The ratios $R_{o} / R^{\prime}$ and $\left(k R_{o} / k_{2}-k_{1}\right) / A^{\prime}$ represent the marker distribution volumes of the rumen and abomasum. DM contents were calculated from these volumes using the proportions of DM in digesta and filtrate from each organ.

The rumen concentration $v$. time curves for $\left[{ }^{51} \mathrm{Cr}\right.$ ]EDTA in Expt 2 appeared to show small cyclical variations (see Fig. I A). The rumen data were therefore analysed again making $k_{1}$ in equation ( $\mathrm{I}$ ) a sinusoidal function of time (with time period equal to $24 \mathrm{~h}$ ).

Thus

$$
k_{1}(t)=c+r \sin \frac{\pi}{\mathrm{I} 2}\left(t+t^{\prime}\right)
$$

where $c$ is the base value of $k_{1}\left(\mathrm{~h}^{-1}\right), r$ represents the amplitude of the fluctuations in $k_{1}\left(\mathrm{~h}^{-1}\right), t$ is the time after dosing (h) and $t^{\prime}$ is the temporal displacement (h) of the sine curve. 
Table I. Parameter values describing the passage of $\left[{ }^{51} \mathrm{Cr}\right] E D T A$ and $\left[{ }^{103} \mathrm{Ru}\right] P$ through the stomach of sheep given concentrate diets in Expt I (model I, p. 73). ${ }^{51} \mathrm{Cr}$ and ${ }^{103} \mathrm{Ru}$ were assayed in fluid obtained by filtration of rumen and abomasal digesta.

(Mean values with standard errors)

\begin{tabular}{|c|c|c|c|c|c|c|}
\hline \multirow[b]{2}{*}{ Marker } & \multirow[b]{2}{*}{ Diet } & \multirow[b]{2}{*}{$\begin{array}{c}\text { Sheep } \\
\text { no. }\end{array}$} & \multicolumn{2}{|c|}{ Rate constants $\left(\mathrm{h}^{-1}\right)$} & \multirow[b]{2}{*}{$\begin{array}{l}\text { Time delay (h) } \\
\text { (omasum) }\end{array}$} & \multirow[b]{2}{*}{$A \dagger$} \\
\hline & & & $k_{1}$ (rumen) & $k_{2}$ (abomasum) & & \\
\hline$\left.{ }^{[51} \mathrm{Cr}\right] \mathrm{EDTA}$ & $\mathrm{U}$ & $\begin{array}{l}I \\
2 \\
3\end{array}$ & $\begin{array}{l}0.0446(0.0015) \\
0.0507(0.0013) \\
0.0362(0.0013)\end{array}$ & $\begin{array}{l}0.56(0.13) \\
0.82(0.15) \\
0.46(0.09)\end{array}$ & $\begin{array}{l}0.57(0.38) \\
0.53(0.26) \\
0.28(0.41)\end{array}$ & $\begin{array}{l}0.99 \\
0.99 \\
0.99\end{array}$ \\
\hline & $\mathbf{T}$ & $\begin{array}{l}1 \\
2 \\
3 \\
4\end{array}$ & $\begin{array}{l}0.0316(0.0012) \\
0.0446(0.0010) \\
0.0882(0.0011) \\
0.0705(0.0024)\end{array}$ & $\begin{array}{l}0.81(0.40) \\
0.61(0.07) \\
0.42(0.02) \\
0.52(0.08)\end{array}$ & $\begin{array}{l}0.24(0.92) \\
0.64(0.19) \\
0.36(0.09) \\
0.41(0.29)\end{array}$ & $\begin{array}{l}0.99 \\
0.996 \\
0.999 \\
0.99\end{array}$ \\
\hline Mean $\theta^{*}$ & & & $21 \cdot 3(2 \cdot 7)$ & $1.8(0.2)$ & & \\
\hline$\left[{ }^{103} \mathrm{Ru}\right] \mathrm{P}$ & $\mathrm{U}$ & $\begin{array}{l}1 \\
2 \\
3\end{array}$ & $\begin{array}{l}0.0324(0.0018) \\
0.0285(0.0008) \\
0.0210(0.0011)\end{array}$ & $\begin{array}{l}0.25(0.03) \\
0.53(0.07) \\
0.40(0.04)\end{array}$ & $\begin{array}{l}0.0 \\
0.67(0.19) \\
0.0\end{array}$ & $\begin{array}{l}0.98 \\
0.99 \\
0.98\end{array}$ \\
\hline & $T$ & $\begin{array}{l}1 \\
2 \\
3 \\
4\end{array}$ & $\begin{array}{l}0.0171(0.0010) \\
0.0307(0.0019) \\
0.0403(0.0024) \\
0.0358(0.0022)\end{array}$ & $\begin{array}{l}0.44(0.05) \\
0.20(0.02) \\
0.23(0.02) \\
0.27(0.05)\end{array}$ & $\begin{array}{l}0.0 \\
0.0 \\
0.0 \\
0.34(0.36)\end{array}$ & $\begin{array}{l}0.98 \\
0.97 \\
0.97 \\
0.97\end{array}$ \\
\hline Mean $\theta$ & & & $36 \cdot 8(4 \cdot 5)$ & $3.4(0.5)$ & & \\
\hline
\end{tabular}

* Mean retention time, $\theta(\mathrm{h})$ is the reciprocal of the rate constant $k$.

$\dagger$ Fisher's $A$ measures the proportion of the variance accounted for in fitting the model (Cornish, 1950).

Using $k_{1}(t)$ from equation (5) the solution of equation ( 1 ) becomes

$$
R(t)=R_{0} \exp \left[-\int_{0}^{t} k_{1}(w) d w\right] .
$$

The analogous extension to equation (2) has complications which are far from trivial. Firstly, should the abomasal rate constant $k_{2}$ also be made a sinusoidal function of time? Secondly, there is no simple analytical solution to the extended version of equation (2) even if only $k_{1}(t)$ is assumed to be sinusoidal. Thirdly, it is doubtful if there are sufficient data, especially in the first few hours after dosing, to allow even moderately precise estimation of the sine wave parameters. Consequently no attempt was made to incorporate cyclical variations in rate constants in the analyses which included the abomasal data. However, the use of an 'average' value for each of the rate constants $k_{1}$ and $k_{2}$ ought not to seriously bias parameter estimates in model $I$.

Tests of models and standard error estimates were all based on the usual linear approximation to a non-linear model and are therefore only approximate.

\section{RESULTS}

Expt 1 . The values obtained for the rate constants and time delays $( \pm \mathrm{SE})$ for $\left[{ }^{51} \mathrm{Cr}\right] \mathrm{EDTA}$ and $\left[{ }^{103} \mathrm{Ru}\right] \mathrm{P}$ in filtrate are shown in Table $\mathrm{I}$. The proportion of variance accounted for by regression (Fisher's $A$ statistic; Cornish, 1950) indicated that model I accurately described the data; the variance not accounted for was less than $1 \%$ for $\left[{ }^{51} \mathrm{Cr}\right]$ EDTA and less than $3 \%$ for $\left[{ }^{103} \mathrm{Ru}\right] \mathrm{P}$. As a consequence of limited data in the first few hours after dosing, sharp 
Table 2. Fluid volumes ( $l$ ) of the rumen and abomasum of sheep given concentrate diets (Expt $\mathrm{I})$

(Mean values with standard errors)

$\begin{array}{cccc}\text { Diet } & \begin{array}{c}\text { Sheep } \\ \text { no. }\end{array} & \text { Rumen volume } & \text { Abomasal volume } \\ \text { U } & \text { I } & 4.46(0.08) & 0.67(0.15) \\ & 2 & 4.38(0.07) & 0.32(0.06) \\ & 3 & 5.07(0.09) & 0.58(0.12) \\ T & \text { I } & 4.38(0.08) & 0.33(0.16) \\ & 2 & 4.57(0.06) & 0.39(0.05) \\ & 3 & 2.94(0.02) & 0.66(0.03) \\ & 4 & 3.85(0.08) & 0.59(0.09)\end{array}$

Table 3. Parameter values describing the passage of $\left[{ }^{51} \mathrm{Cr}\right] E D T A$ and $\left[{ }^{103} \mathrm{Ru}\right] P$ through the stomach of sheep given concentrate diets in Expt 2 (model I, p. 73). ${ }^{51} \mathrm{Cr}$ and ${ }^{103} \mathrm{Ru}$ were assayed in rumen and abomasal digesta and in fluid obtained from digesta by filtration; ${ }^{51} \mathrm{Cr}$ values were expressed per $g$ water and ${ }^{103} R u$ values were expressed per $g$ dry matter

(Mean values with standard errors)

\begin{tabular}{|c|c|c|c|c|c|}
\hline \multirow[b]{2}{*}{ Marker } & \multirow{2}{*}{$\begin{array}{l}\text { Sheep } \\
\text { no. }\end{array}$} & \multicolumn{2}{|c|}{ Rate constants $\left(\mathrm{h}^{-1}\right)$} & \multirow{2}{*}{$\begin{array}{l}\text { Time delay (h) } \\
\tau \text { (omasum) }\end{array}$} & \multirow[b]{2}{*}{$A^{\dagger}$} \\
\hline & & $k_{1}$ (rumen) & $k_{8}$ (abomasum) & & \\
\hline$\left[{ }^{51} \mathrm{Cr}\right]$ EDTA in filtrate & $\begin{array}{l}1 \\
2 \\
5 \\
6\end{array}$ & $\begin{array}{l}0.0707(0.0020) \\
0.0437(0.0011) \\
0.0200(0.0012) \\
0.0274(0.0007)\end{array}$ & $\begin{array}{l}1.09(0.37) \\
0.62(0.15) \\
0.56(0.12) \\
0.42(0.08)\end{array}$ & $\begin{array}{l}0.77(0.44) \\
0.17(0.52) \\
1.48(0.24) \\
0.18(0.48)\end{array}$ & $\begin{array}{l}0.99 \\
0.99 \\
0.99 \\
0.99\end{array}$ \\
\hline Mean $\theta^{*}$ & $\begin{array}{l}1,2 \\
5,6\end{array}$ & $\begin{array}{l}I 8 \cdot 5 \\
43 \cdot 3\end{array}$ & $\begin{array}{l}I \cdot 3 \\
2 \cdot I\end{array}$ & & \\
\hline$\left[{ }^{103} \mathrm{Ru}\right] \mathrm{P}$ on small particles & $\begin{array}{l}I \\
2 \\
5 \\
6\end{array}$ & $\begin{array}{l}0.0325(0.0012) \\
0.0229(0.0007) \\
0.0103(0.0007) \\
0.0112(0.0006)\end{array}$ & $\begin{array}{l}0.61(0.08) \\
0.87(0.12) \\
0.79(0.09) \\
0.27(0.03)\end{array}$ & $\begin{array}{l}0.89(0.19) \\
1.05(0.17) \\
1.40(0.11) \\
0.35(0.30)\end{array}$ & $\begin{array}{l}0.99 \\
0.99 \\
0.96 \\
0.97\end{array}$ \\
\hline Mean $\theta$ & $\begin{array}{l}1,2 \\
5,6\end{array}$ & $\begin{array}{l}37 \cdot 3 \\
93 \cdot 2\end{array}$ & $\begin{array}{l}1.4 \\
2.5\end{array}$ & & \\
\hline$\left[{ }^{103} \mathrm{Ru}\right] \mathrm{P}$ on large particles & $\begin{array}{l}\text { I } \\
2 \\
5 \\
6\end{array}$ & $\begin{array}{l}0.0374(0.0049) \\
0.0187(0.0017) \\
0.0126(0.0035) \\
0.0195(0.0016)\end{array}$ & $\begin{array}{l}0.14(0.03) \\
0.44(0.18) \\
0.73(0.27) \\
0.10(0.01)\end{array}$ & $\begin{array}{l}0.0 \\
0.47(0.87) \\
1.63(0.28) \\
0.0\end{array}$ & $\begin{array}{l}0.84 \\
0.88 \\
0.68 \\
0.93\end{array}$ \\
\hline Mean $\theta$ & $\begin{array}{l}1,2 \\
5,6\end{array}$ & $\begin{array}{l}40 \cdot I \\
65 \cdot 4\end{array}$ & $\begin{array}{l}4 \cdot 7 \\
5.8\end{array}$ & & \\
\hline
\end{tabular}

* Mean retention time, $\theta(\mathrm{h})$ is the reciprocal of the rate constant $k$.

$\dagger$ Fisher's $A$ measures the proportion of the variance accounted for in fitting the model (Cornish, 1950).

discrimination between time spent in the omasum and the abomasum was not possible. The total mean time (i.e. $\tau+\mathrm{I} / k_{2}$ ) is more accurately determined; for example, the mean time spent by [ $\left.{ }^{51} \mathrm{Cr}\right] E D T A$ in the omasum plus abomasum of sheep I given diet $T$ was estimated to be $\mathrm{I} \cdot 47 \pm 0.3 \mathrm{I} h$ whereas the separate estimated times were, respectively, $0.24 \pm 0.92 \mathrm{~h}$ and $\mathrm{I} \cdot 23 \pm 0 \cdot 6 \mathrm{I} \mathrm{h}$.

In some instances with $\left[{ }^{103} \mathrm{Ru}\right] \mathrm{P}$ data, negative estimates of time delay were obtained. Since a negative value is biologically unacceptable and the negative estimates were not significantly different from zero, the model was refitted on such occasions with the time delay constrained to be zero.

$\left[{ }^{103} \mathrm{Ru}\right] \mathrm{P}$ in digesta filtrate had a longer mean retention time in the rumen than did $\left.{ }^{51} \mathrm{Cr}\right]-$ EDTA (Table I). Mean retention times in the abomasum were also greater for $\left[{ }^{103} \mathrm{Ru}\right] \mathrm{P}$. The 

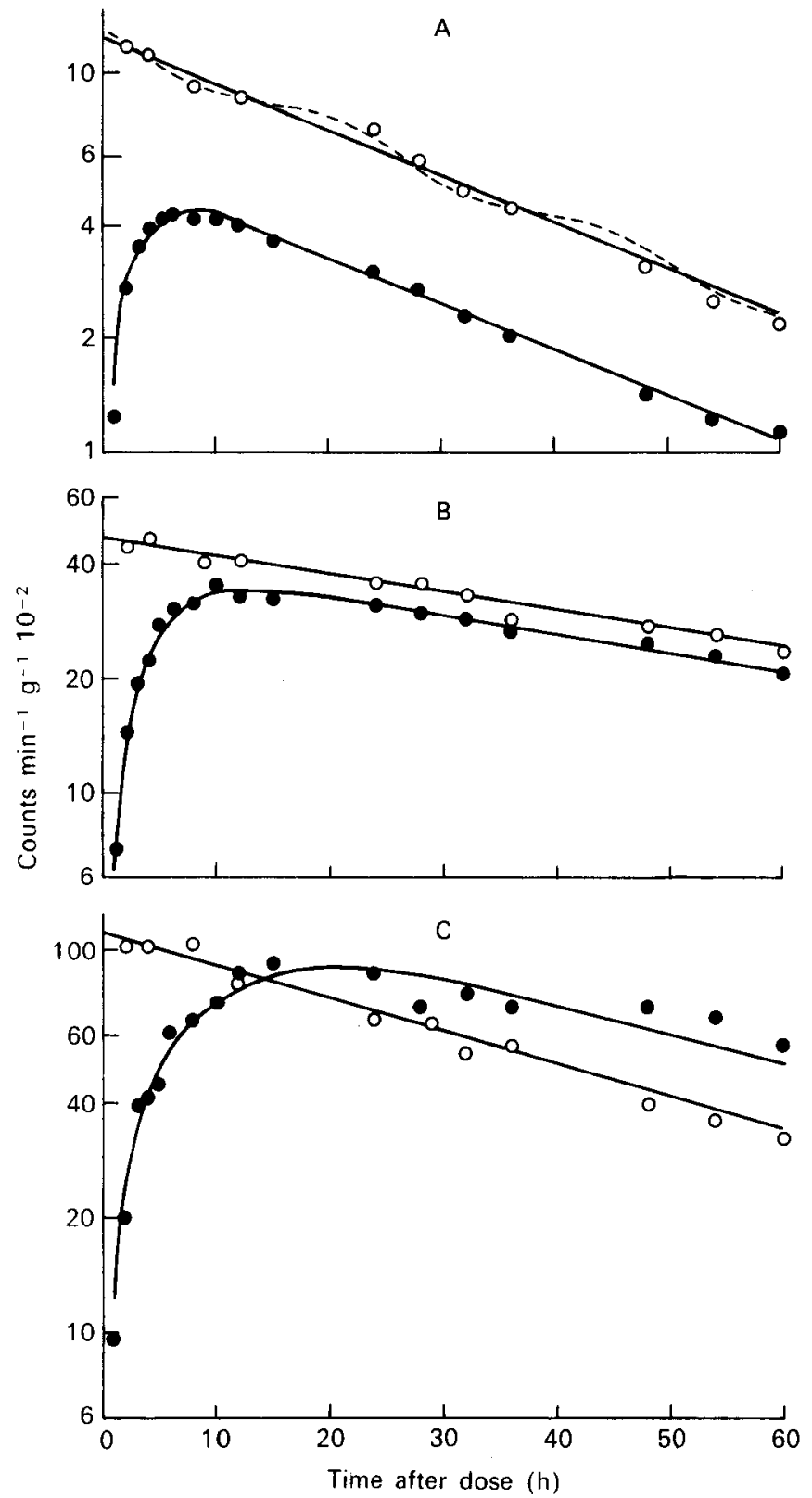

Fig. I. Changes in concentration of $\left[{ }^{51} \mathrm{Cr}\right] \mathrm{EDTA}$ in filtrate water $(\mathrm{A})$ and $\left[{ }^{103} \mathrm{Ru}\right] \mathrm{P}$ associated with small particles $(B)$ and large particles $(C)$ in the rumen $(O)$ and abomasum $(\bullet)$ after a dose of the markers into the rumen of sheep 6 (Expt 2). The curves calculated using the combined analysis of rumen and abomasal data (model $\mathrm{I} ;-\longrightarrow$ ) and the sine wave analysis (equation $5 ;---$ ) are shown.

mean retention times for $\left[{ }^{103} \mathrm{Ru}\right] \mathrm{P}$ and $\left[{ }^{51} \mathrm{Cr}\right] \mathrm{EDTA}$ in the abomasum ( $\pm \mathrm{SE}$ of the mean), determined independently after a separate dose of the markers into the abomasum were, respectively, $2.9 \pm 0.5 \mathrm{~h}$ and $\mathrm{I} \cdot 9 \pm 0.3 \mathrm{~h}$; these values were not significantly different from those obtained in the combined analysis. The mean retention times of the markers in the rumen were very similar to the values obtained from the rumen sampling alone which were 
Table 4. Sine wave analysis of the disappearance of $\left[{ }^{51} \mathrm{Cr}\right] E D T A$ from the rumen of sheep given concentrate diets and comparison with the rate constants obtained from the combined analysis of rumen and abomasum data and the analysis of rumen data alone (Expt 2)

(Mean values with standard errors in parentheses)

\begin{tabular}{|c|c|c|c|c|c|}
\hline \multirow[b]{2}{*}{$\begin{array}{c}\text { Sheep } \\
\text { no. }\end{array}$} & \multicolumn{3}{|c|}{ Rate constants $\left(h^{-1}\right)$} & \multirow[b]{2}{*}{$\begin{array}{c}\text { Amplitude } \\
\text { of sine } \\
\text { wave } \\
r\left(h^{-1}\right)\end{array}$} & \multirow[b]{2}{*}{$\begin{array}{l}\text { Time of day } \\
\text { for sine-wave } \\
\text { maximum }\end{array}$} \\
\hline & $\begin{array}{l}\text { Combined analysis } \\
\text { of rumen and } \\
\text { abomasum data } \\
k_{1}\end{array}$ & $\begin{array}{c}\text { Analysis of } \\
\text { rumen data } \\
\text { alone } \\
k_{1}\end{array}$ & $\begin{array}{c}\text { Analysis of rumen } \\
\text { data using sine } \\
\text { wave } \\
\text { C }\end{array}$ & & \\
\hline $\mathbf{I}$ & $\begin{array}{c}0.0707 \\
(0.0020)\end{array}$ & $\begin{array}{c}0.0730 \\
(0.0018)\end{array}$ & $\begin{array}{c}0.0681 \\
(0.0080)\end{array}$ & $\begin{array}{c}0.0217 \\
(0.0085)\end{array}$ & $\begin{array}{l}13.40 \text { hours } \\
\text { (2 h IO min) }\end{array}$ \\
\hline 2 & $\begin{array}{c}0.0437 \\
(0.0011)\end{array}$ & $\begin{array}{c}0.0439 \\
(0.0016)\end{array}$ & $\begin{array}{c}0.0449 \\
(0.0018)\end{array}$ & $\begin{array}{c}0.0167 \\
(0.0122)\end{array}$ & $\begin{array}{l}\text { I } 1.30 \text { hours } \\
\text { (I h } 10 \mathrm{~min} \text { ) }\end{array}$ \\
\hline 5 & $\begin{array}{c}0.0200 \\
(0.0012)\end{array}$ & $\begin{array}{c}0.0198 \\
(0.0016)\end{array}$ & $\begin{array}{c}0.0189 \\
(0.0011)\end{array}$ & $\begin{array}{c}0.0146 \\
(0.0053)\end{array}$ & $\begin{array}{l}\text { I } 7.30 \text { hours } \\
\text { (I h } 40 \mathrm{~min} \text { ) }\end{array}$ \\
\hline 6 & $\begin{array}{c}0.0274 \\
(0.0007)\end{array}$ & $\begin{array}{c}0.0275 \\
(0.001 \mathrm{I})\end{array}$ & $\begin{array}{c}0.0273 \\
(0.0008)\end{array}$ & $\begin{array}{c}0.0169 \\
(0.0067)\end{array}$ & $\begin{array}{l}\text { o8.ro hours } \\
\text { (I h } 30 \text { min) }\end{array}$ \\
\hline
\end{tabular}

Table 5. The quantities of water and dry matter in the rumen and abomasum of sheep given concentrate diets in Expt 2

(Mean values with standard errors)

$\begin{array}{lccc} & \begin{array}{c}\text { Sheep } \\ \text { no. }\end{array} & \text { Rumen } & \text { Abomasum } \\ \text { Water (l) } & \text { I } & 3.8 \text { I }(0.06) & 0.45(0.14) \\ & 2 & 5.00(0.07) & 0.57(0.13) \\ & 5 & 6.18(0.12) & 0.54(0.54) \\ & 6 & 5.63(0.07) & 0.85(0.16) \\ \text { Dry matter (kg) } & \text { I } & 0.52(0.05) & 0.017(0.006) \\ & 2 & 0.72(0.03) & 0.028(0.006) \\ & 5 & 1.14(0.07) & 0.028(0.007) \\ & 6 & 0.97(0.05) & 0.052(0.012)\end{array}$

( \pm SE of the mean) $2 \mathrm{I} \cdot 4 \pm 2 \cdot 9 \mathrm{~h}$ and $36 \cdot 5 \pm 5 \cdot 2 \mathrm{~h}$ for $\left[{ }^{51} \mathrm{Cr}\right]$ EDTA and $\left[{ }^{103} \mathrm{Ru}\right] \mathrm{P}$ respectively (Faichney, $1975 b$ ). The distribution volume of $\left[{ }^{51} \mathrm{Cr}\right]$ EDTA in the rumen ranged from 2.94 to $5.07 \mathrm{l}$ of filtrate and in the abomasum ranged from 320 to $670 \mathrm{ml}$ (Table 2).

Expt 2. The rate constants and time delays ( $\pm \mathrm{SE}$ ) for the markers associated with different components of digesta are shown in Table 3. Model $\mathrm{I}$ again accounted for most of the variance in the $\left[{ }^{51} \mathrm{Cr}\right] E D T A$ and small particle $\left[{ }^{103} \mathrm{Ru}\right] \mathrm{P}$ data. The cumulative errors in the derived data for large particle $\left[{ }^{103} \mathrm{Ru}\right] \mathrm{P}$ are reflected in the lower proportion of the variance accounted for by the model.

The mean retention times for the markers in the rumen of sheep I and 2 (Table 3 ) were within the range obtained in Expt I but were much less than those for sheep 5 and 6 . Microscopic examination of rumen fluid indicated that, whereas sheep I and 2 had in their rumens a large population of protozoa containing starch grains, sheep 5 and 6 had no protozoa and little free starch.

As in Expt $\mathrm{I}$, the mean retention times for $\left[{ }^{51} \mathrm{Cr}\right] \mathrm{EDTA}$ in the rumen were very much less than those for small particle $\left[{ }^{103} \mathrm{Ru}\right] \mathrm{P}$. There did not seem to be much difference between the mean retention times for $\left[{ }^{103} \mathrm{Ru}\right] \mathrm{P}$ associated with large and with small particles in sheep I and 2 but there was a substantial difference in sheep 5 and 6 ; on average, $\left[{ }^{103} \mathrm{Ru}\right] \mathrm{P}$ associated with small particles was retained longer than $\left[{ }^{103} \mathrm{Ru}\right] \mathrm{P}$ associated with large particles. In this 
Table 6. Apparent transfer quotients calculated from the concentration v. time curves* for sheep given concentrate diets in Expt 2

$\begin{array}{cccc}\begin{array}{c}\text { Sheep } \\ \text { no. }\end{array} & \begin{array}{c}\left.{ }^{51} \mathrm{Cr}\right] \text { EDTA in } \\ \text { filtrate water }\end{array} & \begin{array}{c}{\left[{ }^{108} \mathrm{Ru}\right] \mathrm{P} \text { on }} \\ \text { small particles }\end{array} & \begin{array}{c}{\left[{ }^{103} \mathrm{Ru}\right] \mathrm{P} \text { on }} \\ \text { large particles }\end{array} \\ \text { I } & 0.55 & 1.55 & 1.18 \\ 2 & 0.62 & 1.42 & 0.80 \\ 5 & 0.4 \mathrm{I} & 0.90 & \mathrm{I} \cdot 29 \\ 6 & 0.43 & 0.83 & \mathrm{I} \cdot 2 \mathrm{I}\end{array}$

* The integral of the abomasal curve divided by the integral of the rumen curve.

experiment there was little difference between the mean retention times of $\left[{ }^{51} \mathrm{Cr}\right] \mathrm{EDTA}$ and small particle $\left[{ }^{103} \mathrm{Ru}\right] \mathrm{P}$ in the abomasum; $\left[{ }^{103} \mathrm{Ru}\right] \mathrm{P}$ associated with large particles was retained somewhat longer.

The estimated delay times, which represent the omasum, were very variable but, for sheep I, 5 and 6, values were of similar magnitude within sheep for $\left[{ }^{51} \mathrm{Cr}\right]$ EDTA and small particle $\left[{ }^{103} \mathrm{Ru}\right] \mathrm{P}$. The time delay was set at zero for the analysis of the data for large particle $\left[{ }^{103} \mathrm{Ru}\right] \mathrm{P}$ from sheep $I$ and 6 because of negative estimates as in Expt 1 . The standard errors for the time delay are relatively large for the reasons detailed above.

The calculated curves for $\left[{ }^{51} \mathrm{Cr}\right]$ EDTA in filtrate water and $\left[{ }^{103} \mathrm{Ru}\right] \mathrm{P}$ in small particles and large particles are shown for sheep 6 in Fig. I. Also shown, in Fig. I A, is the curve obtained when $k_{1}$ is assumed to be a sinusoidal function of time (equation (5)). The parameter values $( \pm \mathrm{SE}$ ) calculated for equation (5) are shown in Table 4 and the base value of the rate constant is compared with the values obtained by analysis of the rumen data alone and by the combined analysis of rumen and abomasal data. The rate constants derived from the three types of analysis were similar. Compared with the analysis of the rumen data alone, the use of equation (5) reduced the residual variance by $48 \%$ for sheep I, $2 \%$ for sheep $2,47 \%$ for sheep 5 and $56 \%$ for sheep 6 .

Sheep 5 and 6, which were free of protozoa, had more water and DM in their rumens than sheep I and 2 (Table 5). The DM contents of their rumen and abomasal digesta, I5. I and $5.5 \%$ respectively, were also greater than those of sheep I and $2,12.3$ and $4.2 \%$ respectively. The proportions of the DM present in the rumen as small particles averaged 0.464 for sheep 5 and 6 and 0.562 for sheep $I$ and 2.

\section{DISCUSSION}

The representation of the stomach of the sheep as two mixing compartments and a time delay provided a very good description of the changes with time of marker concentrations in the rumen and abomasum after a single dose into the rumen. The proportion of the variance accounted for in fitting the model was 0.99 or more for $\left[{ }^{51} \mathrm{Cr}\right] \mathrm{EDTA}, 0.98$ for $\left[{ }^{103} \mathrm{Ru}\right] \mathrm{P}$ associated with small particles and 0.83 for $\left[{ }^{103} \mathrm{Ru}\right] \mathrm{P}$ calculated to be adsorbed to large particles. However, since the delay time representing the omasum had to be set at zero for the analysis of $\left[{ }^{103} \mathrm{Ru}\right] \mathrm{P}$ data for some sheep and the standard errors for the positive values were large, it is clear that the techniques described in this paper cannot provide reliable estimates for omasal transit times. This is because the accuracy with which the first part of the curve can be defined is limited by the fact that, as mixing of the marker dose with rumen contents is not instantaneous, the marker concentrations in digesta reaching the abomasum in the first few hours after dosing are somewhat unreliable.

As all the marker appearing in the abomasum must come from the rumen, the transfer quotient should be unity; apparent transfer quotients calculated from the integrals of the 
concentration $v$. time curves are shown in Table 6. For $\left[{ }^{51} \mathrm{Cr}\right] \mathrm{EDTA}$, the fact that the apparent transfer quotient is less than one reflects dilution due to abomasal secretion and, perhaps, saliva that has not mixed with rumen contents (Engelhardt, 1974). Although DM in abomasal secretions could cause deviations in the values for $\left.{ }^{103} \mathrm{Ru}\right] \mathrm{P}$ in the small particle fraction, the most likely cause of the deviations from unity in the apparent transfer quotients for $\left[{ }^{103} \mathrm{Ru}\right] \mathrm{P}$ in both small and large particle fractions is exchange of $\left[{ }^{103} \mathrm{Ru}\right] \mathrm{P}$ between these fractions. Evidence for such an exchange could not be derived using the techniques described here. Thus a second component could not be distinguished in the rumen curve for small particle $\left[{ }^{103} \mathrm{Ru}\right] \mathrm{P}\left(k_{2}\right.$ in model 3 did not differ from zero) and the independent analyses of $\left[{ }^{103} \mathrm{Ru}\right] \mathrm{P}$ associated with small and large particles using model I provided good descriptions of the data. However, in three of the four sheep, $k_{1}$ for small particle $\left[{ }^{103} \mathrm{Ru}\right] \mathrm{P}$ was less than $k_{1}$ for large particle [ $\left.{ }^{103} \mathrm{Ru}\right] \mathrm{P}$ (Table 3) which would be consistent with a net transfer of $\left[{ }^{103} \mathrm{Ru}\right] \mathrm{P}$ from the large to the small particle fraction, i.e. $k_{1}$ for large particle $\left[{ }^{103} \mathrm{Ru}\right] \mathrm{P}$ from model $\mathrm{I}$ was equivalent to $\left(k_{1}+k_{2}\right)$ in model 3 .

$\left[{ }^{103} \mathrm{Ru}\right] \mathrm{P}$ does transfer from labelled to unlabelled particles. Although no $\left[{ }^{103} \mathrm{Ru}\right] \mathrm{P}$ can be detected in solution after incubation with plant particles or microbial cells suspended in water, when large particles labelled with $\left[{ }^{103} \mathrm{Ru}\right] \mathrm{P}$ were incubated at $39^{\circ}$ in vitro with a similar weight of killed rumen bacteria in suspension, it was found that $\left[{ }^{103} \mathrm{Ru}\right] \mathrm{P}$ transferred to bacterial DM, rapidly at first and then more slowly, approaching equilibrium in $24 \mathrm{~h}$ (Faichney, unpublished results).

In the rumen, the effect of exchange of $\left[{ }^{103} \mathrm{Ru}\right] \mathrm{P}$ between large and small particles would be to underestimate the retention times of both fractions as determined by model 1 . Transfer in one direction would lead to underestimation of retention time for the fraction from which the transfer occurred. The fact that unlabelled small and large particles entered the rumen in the diet and unlabelled small particles were generated (new microbial cells) suggests that there may have been net transfer of $\left[{ }^{103} \mathrm{Ru}\right] \mathrm{P}$ from large to small particles so that the mean retention time of large particles would have been underestimated. The results obtained suggest that the small particle fraction, which was largely composed of micro-organisms, may not be removed from the rumen as rapidly as solutes. This finding is contrary to the assumption that small particles would be expected to pass from the rumen at a rate similar to that of the liquid phase (Hungate, I966; Demeyer \& Van Nevel, I975), but it is not inconsistent with the observations of Walker and co-workers who found that the mean retention time of microbial ${ }^{35} \mathrm{~S}$ was longer than that of $\left[{ }^{51} \mathrm{Cr}\right]$ EDTA (D. J. Walker, personal communication; Egan, Walker, Nader \& Storer, I975) and the suggestion of Weller \& Pilgrim (I974) that protozoa appear to be sequestered in the rumen.

Although the mean retention time for $\left[{ }^{103} \mathrm{Ru}\right] \mathrm{P}$ in the rumen is a function of that for particulate matter, it is clear that the exchange of $\left[{ }^{103} \mathrm{Ru}\right] \mathrm{P}$ which occurs between particle size fractions complicates the interpretation of values obtained using this marker. Much more work is needed before the dynamic behaviour of particulate matter and of adsorbable markers in the rumen can be understood.

In Expt 2 it was found that there were no protozoa in the rumen microbial population of sheep 5 and 6 . It was also found that sheep 5 and 6 had much longer mean retention times of both $\left[{ }^{51} \mathrm{Cr}\right] \mathrm{EDTA}$ and $\left[{ }^{103} \mathrm{Ru}\right] \mathrm{P}$ in the rumen. The rumen contents of these sheep were very thick and glutinous and little gas was evident whereas the rumen contents of sheep I and 2 , which contained a large population of protozoa, were very fluid and frothy. It can be seen from the results reported here that the absence of protozoa from the rumen was also associated both with more water and DM in the rumen and with a higher DM content of the digesta. These results are consistent with those of Eadie, Hyldgaard-Jensen, Mann, Reid \& Whitelaw (1970) who reported a decrease in fractional outflow rate associated with dietary changes resulting in a dramatic reduction of protozoal numbers in the rumen. These dietary 
changes were also associated with an increase in the molar proportion of propionic acid, an increase in volatile fatty acid production and a decrease in ammonia concentration in the rumen (Eadie et al. 1970; Whitelaw, Eadie, Mann \& Reid, 1971). Increased proportions of propionic acid and reduced ammonia levels have been associated with improved efficiency of microbial protein synthesis (Ishaque, Thomas \& Rook, 1971 ; Jackson, Rook \& Towers, 1971). However, increasing rumen fractional outflow rate by rumen infusion or dietary inclusion of buffer salts also improves the efficiency of microbial protein synthesis (Harrison, Beever, Thomson \& Osbourn, 1975, 1976; Thomson, Beever, Mundell, Elderfield \& Harrison, 1975) without changing the protozoal population (Latham \& Sharpe, 1975). It is not possible, therefore, to predict the effect of the differences in protozoal population and rumen turnover seen in this study on metabolism in the rumen.

The daily fluctuations in the rate constant for $\left[{ }^{51} \mathrm{Cr}\right]$ EDTA in the rumen (Table 4, Fig. I A) represent fluctuations in net water flux and these occurred despite continuous feeding under conditions of continuous lighting. However, the room in which the sheep were housed had windows and the feeders were loaded at the same time each morning so the sheep did not lack evidence of a $24 \mathrm{~h}$ cycle. Although observations of water intake were not made, it is possible that the fluctuations observed were the result of a regular drinking pattern.

The function of the ruminant stomach is very complex and remains imperfectly understood. The present work has provided results consistent with the contention that protozoa are sequestered in the rumen (Weller \& Pilgrim, 1974) and has suggested that the retention time for solutes $\left.\left({ }^{51} \mathrm{Cr}\right] \mathrm{EDTA}\right)$ in the rumen may not be the appropriate value for bacteria. It has also shown that, in sheep given concentrate diets, increased fractional outflow rates are associated with the presence $\mathrm{cf}$ protozoa in the rumen. However, it is clear from the results obtained that the mean retention time and rate of removal of particular dietary components from the rumen cannot be simply obtained using adsorbable markers such as $\left[{ }^{103} \mathrm{Ru}\right] \mathrm{P}$.

The authors are indebted to Miss G. A. White, Miss C. Schafer, Mrs J. Williams and Mr R. M. Baxter for technical assistance.

\section{REFERENCES}

Blaxter, K. L., Graham, M. McC. \& Wainman, F. W. (1956). Br. J. Nutr. 1o, 69.

Cornish, E. A. (1950). Aust. J. scient. Res. B 3, 178.

Demeyer, D. \& Van Nevel, C. (I975). In Digestion and Metabolism in the Ruminant, p. 366 [I. W. McDonald and A. C. I. Warner, editors]. Armidale, NSW, Australia: University of New England Publishing Unit. Downes, A. M. \& McDonald, I. W. (1964). Br. J. Nutr. 18, 153.

Eadie, J. M., Hyldgaard-Jensen, J., Mann, S. O., Reid, R. S. \& Whitelaw, F. G. (1970). Br. J. Nutr. 24 , I 57.

Egan, A. R., Walker, D. J., Nader, C. J. \& Storer, G. (1975). Aust. J. agric. Res. 26, 909.

Ellis, W. C., Goodell, R. G. \& Matis, J. H. (1972). J. Anim. Sci. 35, 264.

Engelhardt, W. v. (1974). In Tracer Techniques in Tropical Animal Production, p. I I I. Vienna: International Atomic Energy Agency.

Faichney, G. J. (1975a). In Digestion and Metabolism in the Ruminant, p. 227 [I. W. McDonald and A. C. I. Warner, editors]. Armidale, NSW Australia: University of New England Publishing Unit.

Faichney, G. J. (1975b). Aust. J. agric. Res. 26, 319.

Grovum, W. L. \& Williams, V. J. (1973a). Br. J. Nutr. 30, 23 I.

Grovum, W. L. \& Williams, V. J. (1973b). Br. J. Nutr. 30, 313 .

Harrison, D. G., Beever, D. E., Thomson, D. J. \& Osbourn, D. F. (1975). J. agric. Sci., Camb. 85, 93.

Harrison, D. G., Beever, D. E., Thomson, D. J. \& Osbourn, D. F. (1976). J. Sci. Fd Agric. $27,617$.

Hungate, R. E. (1966). The Rumen and its Microbes. New York: Academic Press.

Ishaque, M., Thomas, P. C. \& Rook, J. A. F. (1971). Nature, New Biol. 231, 253.

Jackson, P., Rook, J. A. F. \& Towers, K. G. (1971). J. Dairy Res. 38, 33.

Latham, M. J. \& Sharpe, M. E. (1975). Proc. Nutr. Soc. 34, I 13 A.

Matis, J. H. \& Hartley, H. O. (197I). Biometrics 27, 77.

Tan, T. N., Weston, R. H. \& Hogan, J. P. (1971). Int. J. appl. Radiat. Isotopes 22, 301. 
Thomson, D. J., Beever, D. E., Mundell, D. C., Elderfield, M. L. \& Harrison, D. G. (1975). Proc. Nutr. Soc. 34, 111 A.

Weller, R. A. \& Pilgrim, A. F. (1974). Br. J. Nutr. 32, 34I.

Weston, R. H. \& Hogan, J. P. (I967). Aust. J. agric. Res. 18, 789.

Whitelaw, F. G., Eadie, J. M., Mann, S. O. \& Reid, R. S. (197I). Br. J, Nutr. 27, 425. 